\title{
Water barrier properties of starch-clay nanocomposite films
}

\section{Propriedades de barreira à água de filmes de nanocompósitos de amido e argila}

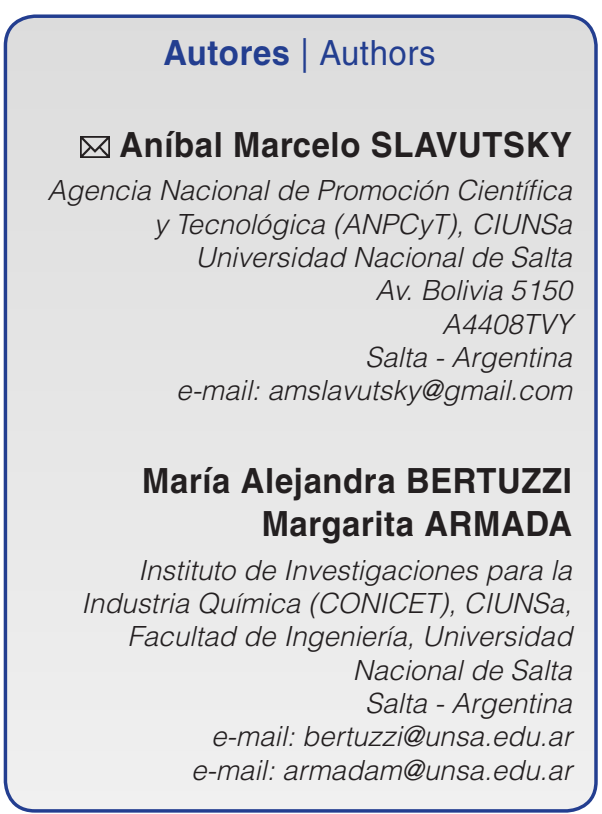

Autor Correspondente / Corresponding Author

Recebido / Received: 03/10/2011 Aprovado / Approved: 19/06/2012 Publicado / Published: set./2012

\section{Summary}

The functional properties of corn starch based films were improved by incorporating nanoclay (Montmorillonite). Nanoclay was incorporated in the polymer matrix using two different methodologies and the films were formed by casting. The effect of film preparation methodology and of the nanoclay concentration on the physicochemical properties of the films was studied. Depending on film preparation method used, intercalated or exfoliated nanocomposite films were obtained. The FTIR spectra showed a strong interaction between the montmorillonite and the starch molecules. Opacity was dependent on the nanoclay dispersion method used. Water vapor solubility and permeability decreased with increasing montmorillonite content and were affected by the dispersion method. Water diffusion was only dependent on the nanoclay content due to the increase in tortuosity of the diffusion path, caused by the nanoparticles. The results showed that the incorporation of $5 \%$ of montmorillonite using an adequate dispersion method, improved the water resistance and barrier properties of corn starch based films. Nanoparticles reduced the damage caused to the properties of these hydrophilic films by the increase in moisture content.

Key words: Starch film; Nanocomposites; Montmorillonite; Water barrier properties.

\section{Resumo}

As propriedades funcionais de filmes à base de amido de milho foram melhoradas pela incorporação de nanoargila (montmorilonita). Nanoargila foi incorporada na matriz polimérica por meio de duas metodologias diferentes e os filmes foram produzidos por casting. Os efeitos da metodologia de preparação e da concentração de nanoargila nas propriedades físico-químicas dos filmes foram estudados. Conforme os métodos de elaboração, filmes intercalados e esfoliados de nanocompósitos foram obtidos. Os espectros FTIR mostraram uma forte interação entre a argila montmorilonita e as moléculas de amido. A opacidade foi dependente do método utilizado para a dispersão da nanoargila. A solubilidade e a permeabilidade ao vapor de água diminuíram com o aumento do teor de montmorilonita e ambas as propriedades foram afetadas pelo método de dispersão. A difusão de água foi dependente do conteúdo de nanoargila, em razão do aumento na tortuosidade do caminho de difusão causado pelas nanopartículas. Os resultados mostraram que a incorporação de $5 \%$ de montmorilonita pelo método de dispersão adequado melhorou a resistência à água e as propriedades de barreira dos filmes de amido de milho. As nanopartículas reduziram os danos causados nas propriedades desses filmes hidrofílicos pelo aumento do teor de umidade.

Palavras-chave: Filme de amido; Nanocompósitos; Montmorilonita; Propriedades de barreira à agua. 


\section{Introduction}

For centuries man has searched for effective substitutes for the natural coatings of foods, in order to keep them fresh and isolated from physical, chemical and/or microbiological contaminants. For many years, the packaging industry has used materials produced from various petroleum-derived monomers to elaborate various types of plastic, which have very good functional properties but also produce serious pollution problems. Thanks to advances in science and the growing interest in the environmental impact of discarded plastics, a new series of materials of biological origin (plant, animal and microbial) have been developed, whose main advantages are that they are fully degradable and even edible in some cases.

Edible films can be defined as a thin layer of material applied on or between food components by dipping, spraying, brushing, etc., to provide a selective barrier against gas, vapor and solute transmission, while also offering mechanical protection (KESTER and FENNEMA, 1986).

The functional properties of biodegradable films and coatings depend on the characteristics of the film forming material. The biopolymers used in film formulations are polysaccharides, proteins and lipids (PARK, 1999). Lipids have good barrier properties against moisture, but little mechanical resistance and a waxy taste. Their ability to reduce the transfer of water is due to their hydrophobic characteristics and highly compact nature (KESTER and FENNEMA, 1986; GUILBERT et al., 1995).

Films based on polysaccharides and proteins have been reported as effective barriers to gas transport $\left(\mathrm{O}_{2}\right.$, $\mathrm{CO}_{2}$ ), although they present high water vapor permeability (FORSELL et al., 2002). The main functional properties (mechanical and barrier properties) of these hydrophilic materials depend on their water content. This is due to strong water vapor interactions with the polymer matrix, affecting the structure (BERTUZZI et al., 2007; MORILLON et al., 2002; RAHMAN, 2003; PERDOMO et al., 2009).

Nanotechnology focuses on the characterization, manufacture and manipulation of biological and non-biological structures smaller than $100 \mathrm{~nm}$. The design of the internal structures on a microscale or nanoscale can improve the functional properties, morphology and stability of the polymer matrices used in edible films and coatings. Currently, the application of nanotechnology in this area is limited and is therefore a wide-open field for scientific research (WEISS et al., 2006; CYRAS et al., 2008).

Nanocomposites are hybrid nanostructured materials. A widely studied type of nanocomposite is a class of hybrid materials composed of organic polymer matrices and nanoclay fillers. The essential nanoclay raw material is montmorillonite (MMT), a 2:1 layered smectite clay mineral with a platey structure. Montmorillonite consists of $1 \mathrm{~nm}$ thick aluminosilicate layers surfacesubstituted with metal cations and stacked in $10 \mu \mathrm{m}$-sized multilayer stacks. Naturally occurring MMT is hydrophilic (POOLE and OWENS, 2007).

In microcomposites, the polymer and clay remain immiscible (phase separation), resulting in agglomeration of the clay in the matrix and poor macroscopic properties of the material. Interaction between the layered silicates and polymer chains may produce two types of nanoscale composites. The intercalated nanocomposites result from the penetration of polymer into the interlayer region of the clay, resulting in an ordered multilayer structure with alternating polymer/inorganic layers at a repeated distance of a few nanometers. The exfoliated nanocomposites involve extensive polymer penetration, with the clay layers delaminated and randomly dispersed in the polymer matrix (AZEREDO, 2009; WEISS et al., 2006). It has been shown that for a glycerol content above $10 \%$ (w/w), the system leads to the formation of an intercalated structure with a clay interlayer spacing of $12 \AA$, corresponding mainly to glycerol intercalation (LIU et al., 2011). Consequently, these results have highlighted the great influence of plasticizers on the clay intercalation/ exfoliation process and hence on the properties of the resulting materials (CHIVRAC et al., 2010). To overcome the limitations induced by polyol plasticizers, some authors have replaced these plasticizers with urea/ formamide (HUANG et al., 2006), formamide (TANG et al., 2008) or urea (CHENG et al., 2005). MMT-Na dispersion into these urea or formamide plasticized starch matrices by a solvent or melt process leads to the formation of intercalated structures. Thus to increase the clay/ matrix affinity, different organo-modified MMT have been incorporated, namely OMMT (CHIVRAC et al., 2009). The use of OMMT with plasticizers such as urea or urea/formamide, has produced great results in the production of exfoliate nanocomposites. Nevertheless, these compounds are eco-toxic and cannot be used to elaborate safe biodegradable "green" materials.

The presence of nanoclay in polymer formulations increases the tortuosity of the diffusive path for a penetrating molecule, and changes the molecular mobility, which enhances the thermal and mechanical properties, confers stability to oxidation, and decreases the solvent absorption, amongst other advantages. It also allows the incorporation of multiple features such as color, aroma, or the ability to act as reservoirs for the controlled release of drugs or fungicides. The incorporation of MMT in proportions below 5\% also offers benefits such as low density, transparency, good flow, better surface properties and recyclability (PERRINE et al., 2008; PAUL 
and ROBESON, 2008). Most published works concerning starch-clay nanocomposites used a complex process of clay dispersions and hot pressing for film formation (TANG et al., 2008; CHIVRAC et al., 2010; CHUNG et al., 2010). In the present study, a simple MMT dispersion procedure followed by starch gelatinization in water at $80^{\circ} \mathrm{C}$, was used. This is an important factor in view of the use of the starch-MMT film as a packaging material for foods and their eventual transference to industry.

The scope of this contribution was to improve the water resistance and water barrier properties of starch films obtained by gel casting with the incorporation of nanoclay, using simple dispersion methodologies that ensure an adequate exfoliation of the MMT layers inside the film matrix, allowing for strong starch-MMT interaction.

\section{Material and methods}

\subsection{Materials}

Commercial, food grade corn starch (Unilever, Argentina) was used as the polymeric matrix for film formulation. Glycerol (Mallinckrodt, USA) was added as the plasticizer. Montmorillonite (MMT) nanoclay was obtained from Minarco S.A. (Buenos Aires, Argentina). The clay sample was homogenized by sieving through a 200-mesh sieve (ASTM). Ethylene glycol (Mallinckrodt, USA) was used for the density determinations. $\mathrm{P}_{2} \mathrm{O}_{5}$ (Mallinckrodt, USA) was used as the desiccant and saturated solutions of $\mathrm{Mg}\left(\mathrm{NO}_{3}\right)_{2}$ (Mallinckrodt, USA) and $\mathrm{NaCl}$ (Mallinckrodt, USA) to obtain environments with 53\% and $75 \% \mathrm{RH}$ (Relative Humidity), respectively.

\subsection{Preparation of MMT solution}

The MMT solution was prepared by stirring MMT and water $(1.5 \% \mathrm{w} / \mathrm{v})$ for $3 \mathrm{~h}$ at $80{ }^{\circ} \mathrm{C}$. The suspension was then centrifuged at $2500 \mathrm{rpm}$ and the insoluble matter discarded. A $20 \mathrm{~mL}$ aliquot was dried in an oven to determine the MMT concentration of the MMT solution. The solution conductivity was determined using a Shott Gerate CG-851 conductimeter (Germany).

\subsection{Film preparation}

Films were prepared using two different methodologies (M1 and M2) :

Method M1: The film-forming solution was formed by mixing $20 \%(\mathrm{w} / \mathrm{w})$ starch in water with $20 \%$ (w/w of the starch) glycerol and different amounts of MMT powder to reach concentrations ranging from 1 to $10 \% \mathrm{w} / \mathrm{w}$ of the starch. The resulting dispersion was stirred for $60 \mathrm{~min}$ at $200 \mathrm{rpm}$. The dispersion was then placed in an ultrasonic bath for $60 \mathrm{~min}$. This method is similar to that used by Cyras et al. (2008).
Method M2: The film-forming solution was prepared by mixing $20 \%(\mathrm{w} / \mathrm{w})$ starch in water with $20 \%(\mathrm{w} / \mathrm{w}$ of the starch) glycerol and the appropriate amount of MMT solution (prepared as described in 2.2.) to obtain concentrations ranging from 1 to $10 \% \mathrm{w} / \mathrm{w}$ of starch. The resulting dispersion was placed in an ultrasonic bath for 60 min.

The difference between the two methods is that in the M2 method, the MMT was previously diluted in water in order to favor the opening of the clay pallets and promote an extensive interaction between the clay layers and the biopolymer chains. However, in the M1 method, the starch, glycerol and MMT were mixed together in one step.

The dispersions obtained by both methods were gelatinized in a shaking water bath at $78-80^{\circ} \mathrm{C}$ for $10 \mathrm{~min}$. This procedure ensures disintegration of the starch granules and the formation of a homogeneous dispersion. The resulting dispersion, while still hot, was poured onto polystyrene plates, which were placed in an air-circulating oven at $35{ }^{\circ} \mathrm{C}$ and $53 \% \mathrm{RH}$ for $15 \mathrm{~h}$. The plates were then removed from the oven and the films peeled off.

\subsection{X-ray diffraction (XRD) and Fourier transform infrared spectroscopy (FTIR)}

$X$-ray diffraction spectra were obtained in a Rigaku MiniFlex diffractometer (Japan), using $\mathrm{Cu} k \alpha$ radiation at $40 \mathrm{kV}$ and $20 \mathrm{~mA}$, over an angular range of $1-40^{\circ}$ with a step size of 0.02 . The samples were previously conditioned at $53 \% \mathrm{RH}$ and $25{ }^{\circ} \mathrm{C}$. IR spectra were obtained using a Perkin Elmer model GX FT-IR spectrometer (USA), equipped with a horizontal attenuated total reflectance (HATR) cell. The spectra were recorded in absorbance units and the wave number ranged from 4000 to $650 \mathrm{~cm}^{-1}$. Each sample was scanned 40 times for spectrum integration, and the scanning resolution was $2 \mathrm{~cm}^{-1}$.

\subsection{Density}

The film density was determined by pycnometry (displacement method). Due to the high solubility of the starch films in water, ethylene glycol was used. The weak ethylene glycol/starch affinity ensures the non-penetration of ethylene glycol into the film matrix. The films prepared with different MMT concentrations and different methodologies were analyzed. The initial dry matter of each film was obtained after drying film specimens in desiccators containing $\mathrm{P}_{2} \mathrm{O}_{5}$ for a week. Measurements were taken in triplicate.

\subsection{Film opacity}

The opacity of the films was determined according to the procedure of Gontard et al. (1992) and the ASTM D 1003-00 (ASTM, 2007) recommendations. The films prepared with different MMT concentrations and MMT 
dispersion methodologies were studied. Film samples were cut into rectangles and placed on the inside of the spectrophotometer cell. The absorbance spectrum (400-800 nm) was recorded for each sample using a 10UV Spectronic Unicam Genesys (USA) spectrophotometer. The film opacity was defined as the area under the recorded curve, determined by an integration procedure. The opacity was expressed as absorbance units $x$ nanometers (AU nm). Samples were previously conditioned at $53 \% \mathrm{RH}$ and $25^{\circ} \mathrm{C}$ and the values reported were averages of at least four readings.

\subsection{Film solubility in water}

The film solubility in water was measured as a percentage of the dry matter of the film dissolved in the water during a period of $24 \mathrm{~h}$. Films prepared with different MMT concentrations and different methodologies were analyzed. The initial dry matter of each film was obtained after drying film specimens in desiccators containing $\mathrm{P}_{2} \mathrm{O}_{5}$ for a week. Samples of approximately $100 \mathrm{mg}$ were weighed and immersed in $20 \mathrm{~mL}$ distilled water at $30^{\circ} \mathrm{C}$, sealed and agitated. Films not dissolved in the water were separated by centrifugation (Sigma 4K10, Germany) at $2500 \mathrm{~g}$, and dried at $40{ }^{\circ} \mathrm{C}$ to determine the remaining dry matter. The tests were carried out in triplicate and the solubility calculated as follows (Equation 1):

Solubility $(\%)=\left(\frac{\text { Initial dry weight }- \text { Final dry weight }}{\text { Initial dry weight }}\right) \cdot 100$

\subsection{Kinetics of water sorption (Water solubility and diffusivity of films)}

The kinetics of water sorption was determined at $25{ }^{\circ} \mathrm{C}$. Film samples (rectangular strips approximately $2 \mathrm{~cm}^{2}$ area) were first freeze-dried (Thermovac Industries Corp, USA) and then stored in a desiccator with $\mathrm{P}_{2} \mathrm{O}_{5}$ for $48 \mathrm{~h}$. Film thickness was measured with an electronic micrometer $(0.001 \mathrm{~mm}$ accuracy, Fowler, Cole-Parmer Instruments Co.). After weighing, they were conditioned at $25{ }^{\circ} \mathrm{C}$ in a desiccator containing a saturated solution of $\mathrm{NaCl}$ to ensure a water activity of 0.75 . The samples were removed at specific intervals and weighed. The water uptake of the samples was plotted versus time and the water solubility and diffusion coefficient obtained from these curves. The method proposed by Crank (1975) for a plane sheet was used to obtain water diffusivity (Equation 2):

$$
\frac{M_{t}}{M_{\infty}}=1-\frac{8}{\pi^{2}} \sum_{m=0}^{\infty} \frac{1}{(2 m+1)^{2}} \exp \left\{-D_{0}(2 m+1)^{2} \pi^{2} t / l^{2}\right\}
$$

Where $t$ is the time, I is the film thickness, $D_{0}$ is the diffusion coefficient, $M_{t}$ is the value for water uptake at time $t$ and $\mathrm{M}_{\infty}$ is the water uptake at equilibrium. The application of this equation was based on the assumption of a constant diffusion coefficient.

\subsection{Water vapor permeability (WVP)}

The apparatus and methodology described in the ASTM E96 (ASTM, 2000) were used to measure the WVP of the film. Film specimens were conditioned for $48 \mathrm{~h}$ in a chamber at $25{ }^{\circ} \mathrm{C}$ and $53 \%$ relative humidity $\left(\mathrm{Mg}\left(\mathrm{NO}_{3}\right)_{2}\right.$ - saturated solution) before being analyzed. The films were sealed on cups containing distilled water. The test cups were placed in a desiccator cabinet maintained at a controlled temperature. A desiccant material was used to provide a specific relative humidity of $0 \%$ and a fan was used to maintain uniform conditions at all test locations over the specimen. Periodic weighings monitored the weight changes. Weight loss was plotted against time and after steady state (straight line) was reached, a further $8 \mathrm{~h}$ were registered. The value for thickness was the mean value of five measurements and was used for the water vapor permeability calculations. The WVP was calculated from the slope $(G)$ of the linear regression of weight loss versus time ( $\mathrm{g} / \mathrm{s}$ ) (Equation 3):

$$
W V P=\frac{G I}{A \Delta p}
$$

Where I is the film thickness (m); $A$ is the exposed area of film $\left(\mathrm{m}^{2}\right)$ and $\Delta \mathrm{p}$ is the water vapor partial pressure difference across the film ( $\mathrm{Pa})$, calculated from the difference between the partial pressure of pure water and that of the desiccant at the experimental temperature.

\subsection{Statistical analysis}

The completely randomized design was analyzed by the analysis of variance (ANOVA) procedure with the GraphPad Prism 5.01 software. Tukey's multiple range test ( $p \leq 0.05$ ) was used to detect differences amongst the mean values of the film properties. The measurements were replicated at least three times for each film tested.

\section{Results and discussion}

A biodegradable film based on a nanocomposite made with starch and MMT, was elaborated. The films were plasticized with glycerol. Due to the hydrophilic nature of both the starch and MMT, an enhanced nano-dispersion state was expected.

To determine the degree of dispersion of the clay in the aqueous solution, the conductivity of the clayaqueous solution was measured. Solutions were prepared following the two clay dispersion methods used in film preparation (Methods M1 and M2). In the M2 method, the MMT was previously diluted in water in order to favor the opening of the clay pallets, and then mixed with the starch and glycerol at the end of of the film forming solution 
preparation process. In the M1 method, the starch, glycerol and MMT were all mixed together in one step. One of the solutions was prepared using a simple dispersion of the MMT powder in water, with no further treatment (M1 method), and the other as described in Section 2.2. (M2 method). The MMT content was $0.4 \%$ (w/w). In the first case, the solution showed a value for conductivity of $191 \mu \mathrm{S} / \mathrm{cm}$, and in the second case, $826 \mu \mathrm{S} / \mathrm{cm}$. The higher conductivity presented by the second solution was due to the better dispersion of the silicate layers and the release of ions into the aqueous medium. The dispersed silicate layers were incorporated into the polymer matrix, thus ensuring a better interaction between both materials in the resulting film. Liu et al. (2011) indicated that mixing glycerol with MMT produced a strong interaction between the two compounds, and that the formulation of exfoliate nanocomposites could be affected.

\subsection{X-ray diffraction and IR spectroscopy}

X-ray diffraction analyses and FTIR spectroscopy were carried out on the starch films, the starch-MMT composite films elaborated using the $\mathrm{M} 1$ and $\mathrm{M} 2$ methods and on the MMT powder.

To investigate the dispersion of the MMT layers, $X$-ray diffraction analyses were carried out on the starch-MMT films. Figure 1 shows the XRD patterns obtained for the MMT, starch and starch-MMT films produced by the $\mathrm{M} 1$ and $\mathrm{M} 2$ methods. In these diffractograms, the MMT pattern displayed an intense diffraction peak at a $2 \theta$ angle of $7.06^{\circ}$, corresponding to a clay inter-layer spacing value of $1.251 \mathrm{~nm}$. Typical peaks could be observed for starch. In the starch-MMT films made with 5 and $10 \%$ of MMT elaborated using the M1 method, the patterns showed a highly intense diffraction peak at $5.14^{\circ}(\mathrm{d}$-spacing $=1.718 \mathrm{~nm})$. In the starch-MMT films with 1 and $3 \%$ of MMT prepared using the M1 method, the peaks at this angle were less intense. The presence of this diffraction peak reveals that these materials were mainly intercalated, and that only a few starch chains had been incorporated into the clay interlayer spacing. This could be due to the strong polar interactions between the hydroxyl groups present in both the polymer chain and in the silicate layers (PARK et al., 2002; CHIVRAC et al., 2010). On the other hand, the patterns of the film samples prepared by the M2 method showed no diffraction peaks in this region, suggesting that the nanocomposites had a completely exfoliated morphology. At $10 \%$ of MMT, a small peak was observed, showing that a limiting MMT concentration exists, beyond which the capacity of the polymer matrix to interact with the silicate layers is exceeded. Cyras et al. (2008), Tang et al. (2008), Chivrac et al. (2010) and Chung et al. (2010) observed similar behaviors for starch-MMT thermoformed films, but in all cases the nanocomposites presented an intercalated structure. Wilhelm et al. (2003) and Majdzadeh-Ardakani et al. (2010) obtained starch-MMT nanocomposite films by casting with an intercalated structure, as shown by their XRD patterns.

It is thought that during the intercalation process the polymer enters the clay galleries and forces apart the layers, thus increasing the gallery spacing (d-spacing) (McGLASHAN and HALLEY, 2003). According to Bragg's law, this would cause a shift in the diffraction
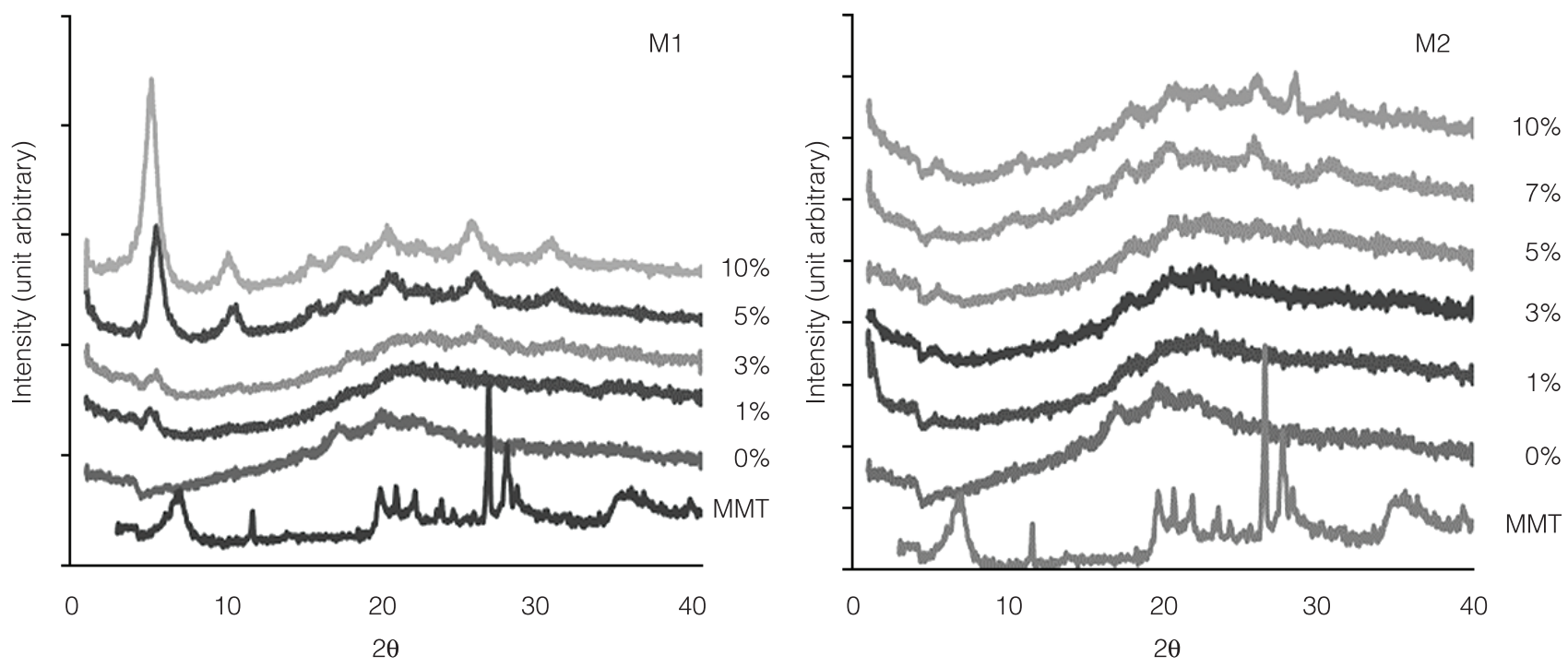

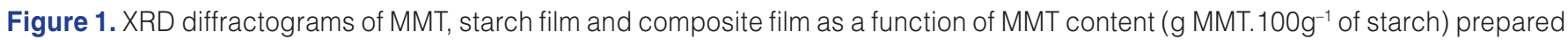
by the M1 and M2 methods. 
peak towards a lower angle. The appearance of the new peak at $2 \theta=5.14(\mathrm{~d}$-spacing $=1.718 \mathrm{~nm})$ with the disappearance of the original nanoclay peak at $2 \theta=7.06$ (d-spacing $=1.251 \mathrm{~nm}$ ) and the increase in d-spacing, indicated the formation of a nanocomposite structure with the intercalation of starch/glycerol chains in the gallery of the MMT silicate layers. When more polymers enter the clay galleries and push the layers further apart, the XRD peak (at the lower angle) becomes wider and wider and finally broadens into the baseline when a complete exfoliated nanocomposite structure is reached (DENNIS et al., 2001).

In Figure 2 the relevant zones of the FTIR spectrum of MMT are shown. Typical bands are found and they coincide with those reported by Cole (2008) and Xiong et al. (2007) for MMT. The wide absorption band at $3432 \mathrm{~cm}^{-1}$ indicates the presence of a large number of $\mathrm{O}-\mathrm{H}$ groups, and the band at $3621 \mathrm{~cm}^{-1}$ indicates free $\mathrm{O}-\mathrm{H}$ groups present in the MMT. The maximal absorptions at 1093 and $465 \mathrm{~cm}^{-1}$ were attributed to the stretching and flexural vibration of Si-O-Si.

Figure 3 shows the FTIR spectra of the starch film and the starch-MMT nanocomposite films elaborated using the $\mathrm{M} 1$ and $\mathrm{M} 2$ methods with $5 \%$ of MMT. In the $\mathrm{O}-\mathrm{H}$ stretching vibration region at $3000-3600 \mathrm{~cm}^{-1}$, there was a shift to a lower wave number in the characteristic starch peak when MMT was added. This is indicative of greater interaction between the starch chains and the MMT via hydrogen bonds. This indicates that in the composite starch-MMT, the hydrogen bonds between

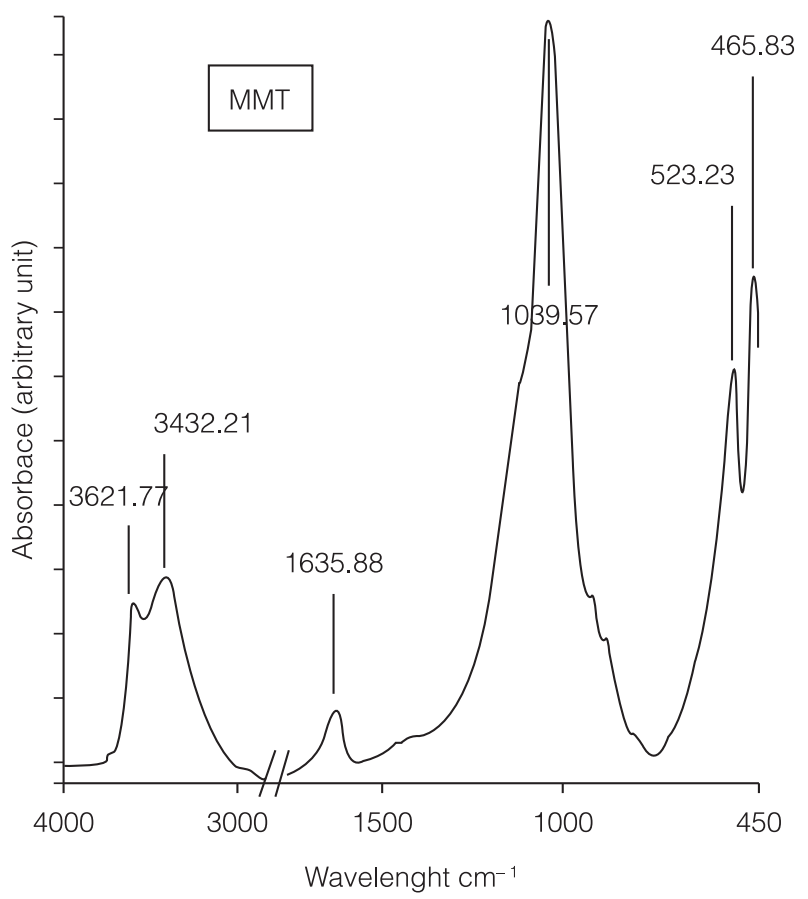

Figure 2. FTIR spectrum of MMT. starch molecules are destroyed, and new hydrogen bonds are formed between the hydroxyl groups of MMT and those of the starch molecules. The disappearance of the band at $3621 \mathrm{~cm}^{-1}$ was reported by other authors, indicating replacement of the free water in the interlayer of MMT, and the formation of new groups with $\mathrm{OH}$ groups of the starch and/or glycerol (CYRAS, et al., 2008; LIU et al., 2011). Characteristic peaks appear in the $1200-800 \mathrm{~cm}^{-1}$ region, which contains skeletal C-O and C-C vibration bands of glycosidic bonds and the pyranoid ring shifts to a lower wave number due to stronger interactions between the starch matrix and MMT. These interactions differ according to the MMT dispersion methodology used, and hence to the quality of the nanoclay dispersed.

\subsection{Density}

Table 1 shows an increase in density with increase in MMT content for both dispersion methods (M1 and M2). This can be explained by the high density of the clay $\left(2.60 \mathrm{~g} . \mathrm{cm}^{-3}\right)$ and there were no differences between the methodologies used (M1 and M2), indicating that incorporation of the clay and the degree of dispersion is unrelated to the final film density.

\subsection{Film opacity}

As shown in Table 1, the opacity of the starch-MMT films depends on the preparation methodology and the MMT content. It was found that the opacity of the films prepared by method M1 increased as MMT content increase. However, a decrease in opacity with MMT content was observed up to values of $5 \%$ of MMT, when the M2 preparation method was used. The differences were due to the way the MMT was either intercalating or exfoliating within the film matrix. The exfoliated structure allowed for a better interaction between the MMT and the starch. Method M1 resulted in a nanocomposite with intercalated MMT while method M2 led to exfoliated MMT, as shown by X-ray spectra. An increase in the MMT content to above $5 \%$ in the M2 method, deteriorated film transparency, because the interaction capacity between the polymer matrix and MMT was exceeded, and the initial opacity values were recovered.

In agreement with the present findings, Ray and Okamoto (2003) also found that improving the dispersion of the nanocomposite within the matrix reduced film opacity. Yu et al. (2003) observed an increase in opacity of polyvinyl alcohol (PVA) films and intercalated MMT. Tunç and Osman (2010) obtained methyl cellulose films with intercalated MMT, and reported that the films lost their transparency and developed opacity. To the contrary, Strawhecker and Manias (2000) found a decrease in opacity of PVA films and MMT dispersed in an exfoliating manner in the matrix. 


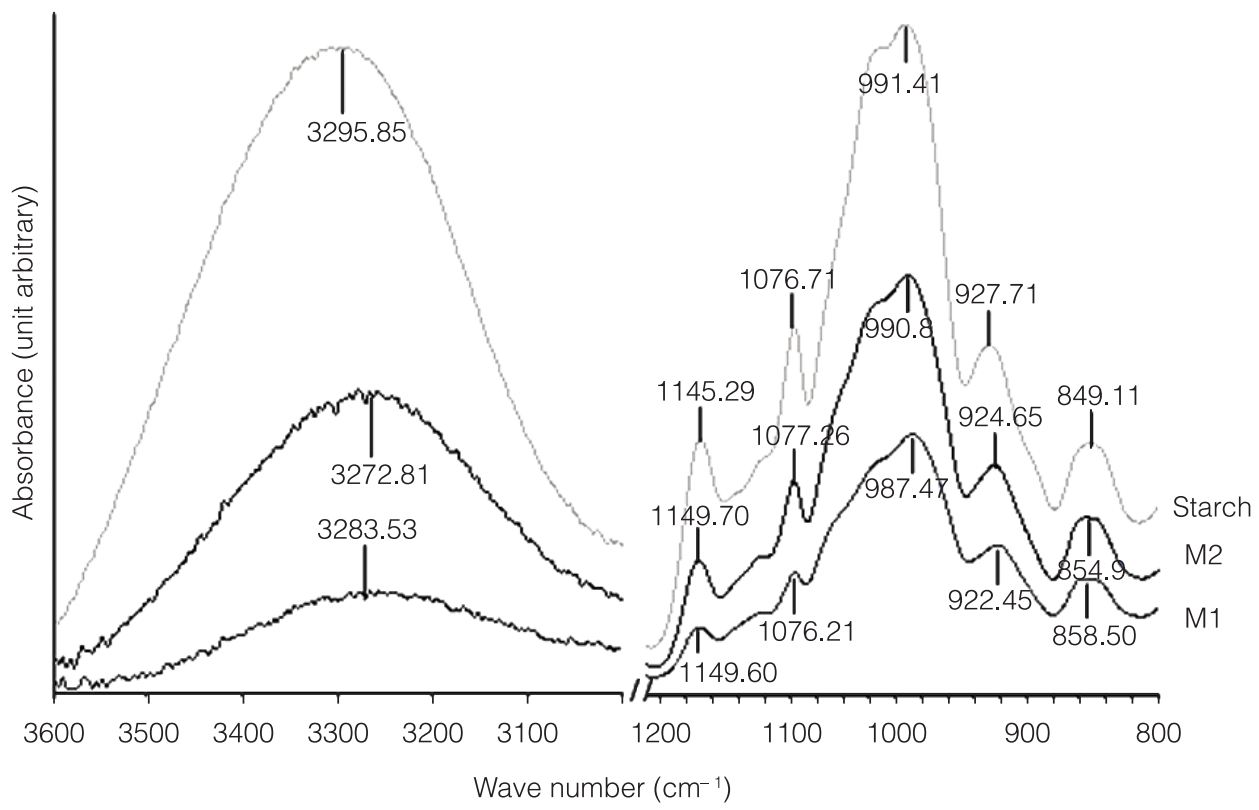

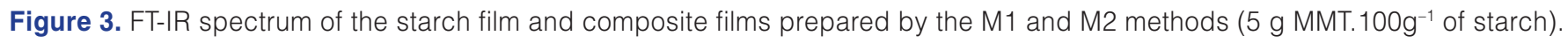

Table 1. Density, opacity and solubility of the starch and composite films prepared by the M1 and M2 methods.

\begin{tabular}{|c|c|c|c|}
\hline $\begin{array}{l}\text { MMT Content } \\
\text { (\%MMT) }\end{array}$ & $\begin{array}{l}\text { Density } \\
\left(\mathrm{g} . \mathrm{cm}^{-3}\right)\end{array}$ & $\begin{array}{l}\text { Opacity } \\
\text { (AU nm) }\end{array}$ & $\begin{array}{c}\text { Solubility } \\
\text { (g soluble matter. } 100 \mathrm{~g}^{-1} \text { film d.b.) }\end{array}$ \\
\hline $0 \%$ & $1.32 \pm 0.07$ & $131 \pm 23$ & $26.65 \pm 1.0$ \\
\hline \multicolumn{4}{|l|}{ M1 } \\
\hline $1 \%$ & $1.32 \pm 0.05$ & $188 \pm 22$ & $24.66 \pm 0.72$ \\
\hline $3 \%$ & $1.48 \pm 0.08$ & $222 \pm 17$ & $24.03 \pm 0.70$ \\
\hline $5 \%$ & $1.53 \pm 0.06$ & $233 \pm 19$ & $24.60 \pm 0.53$ \\
\hline $7 \%$ & $1.59 \pm 0.06$ & $242 \pm 21$ & $22.07 \pm 0.81$ \\
\hline $10 \%$ & $1.62 \pm 0.05$ & $249 \pm 23$ & $21.35 \pm 0.35$ \\
\hline \multicolumn{4}{|l|}{ M2 } \\
\hline $1 \%$ & $1.34 \pm 0.04$ & $120 \pm 19$ & $23.65 \pm 0.70$ \\
\hline $3 \%$ & $1.39 \pm 0.07$ & $114 \pm 25$ & $21.79 \pm 0.39$ \\
\hline $5 \%$ & $1.48 \pm 0.05$ & $93 \pm 19$ & $17.26 \pm 0.55$ \\
\hline $7 \%$ & $1.61 \pm 0.07$ & $101 \pm 15$ & $16.23 \pm 0.40$ \\
\hline $10 \%$ & $1.63 \pm 0.07$ & $116 \pm 17$ & $15.45 \pm 0.57$ \\
\hline
\end{tabular}

*d.b.= Dry Base.

\subsection{Film solubility in water}

Water solubility is an important film property for food packaging applications. Some potential uses may require water insolubility to enhance product integrity and water resistance. However, in other cases, the water solubility of a film before product consumption might be useful, as in the encapsulation of food or additives. The addition of MMT reduces film solubility for both methods used. It was found that film solubility decreased with increase in MMT content (Table 1). Water solubility of the film prepared by the M2 method showed a significant decrease of up to $5 \%$ of MMT. Values above $5 \%$ of MMT content failed to produce a substantial improvement in this property, in the same way found for film opacity (Table 1). This decreasing behavior was more important in films made by the $\mathrm{M} 2$ procedure than in those made by the M1 procedure. It is indicative of a better interaction between the starch chains and the MMT in films obtained by the M2 method, which is facilitated by a better dispersion of the clay in the polymer matrix (exfoliated structure). This increase in intermolecular forces acting between the film components was observed by some other authors, who argued that the hydrogen bonds formed between the MMT and starch chains were stronger than those formed by the MMT and starch with water (DEAN et al., 2008; NING et al., 2009; MAJDZADEH-ARDAKANI et al., 2010). As a consequence, the film solubility in the solvent in which it was prepared, 
decreased. Tunç and Osman (2010) obtained similar results for methylcellulose films.

\subsection{Kinetics of water sorption (Water solubility and Diffusivity in films)}

The equilibrium water uptake $\left(\mathrm{M}_{\infty}\right)$ of samples conditioned at $75 \% \mathrm{RH}$ and $25^{\circ} \mathrm{C}$ was plotted as a function of the MMT content (Figure 4). As the concentration of the filler increased, the composite films absorbed less water, this difference being more pronounced in films prepared by the M2 method. Thus the preparation methodology showed an accentuated effect on water solubility in the composite films. Samples prepared by the M2 method showed an important decrease in solubility with MMT content in the range studied, whereas films prepared by the M1 method only showed a slight decrease in water sorption of the composite film with MMT content. This phenomenon could be ascribed to the formation of strong hydrogen bonding between the starch and MMT, the extension depending on the intercalation/exfoliation of MMT in the film matrix, decreasing the swelling and water absorption of polymeric chains. As a result, reduced water sensitivity of the highly hydrophilic composite films was evident. These results confirm previous findings using RX diffractograms and FT-IR spectra. The results were in the same range of data reported by Almasi et al. (2010) for starch-carboxy methyl cellulose-nanoclay biodegradable films, and by Tunç and Osman (2010) for methyl cellulose-MMT films.

Figure 5 shows the diffusivity of the starch-MMT composite films as a function of MMT content for films prepared by the $\mathrm{M} 1$ and $\mathrm{M} 2$ methods. It shows that the greater the MMT content, the lower the water diffusivity in the films, up to a MMT content of $5 \%$. Diffusivity is almost constant for nanoclay contents above $5 \%$, and similar behavior was observed for both methods. There was no significant difference between the diffusivity coefficients for films prepared by the M1 and M2 methods. Thus the water diffusion process was not affected by the MMT dispersion method. The presence of MMT in the film formulation increased the tortuosity of the diffusive path for the water molecules. As the MMT content increased, so this steric effect also increased, up to and MMT content of $5 \%$. Above this value, the water uptake rate stabilized and maintained almost constant, probably due to segregation of the MMT at high concentrations. The effective water diffusivity values, calculated from the absorption curves using Equation 2 as a function of MMT, are presented in Figure 5. These values were in the same range as those reported by Chivrac et al. (2010) for starch-MMT films obtained by hot compressing, and by Kristo and Biladeris (2006) for pullulan films reinforced with starch nanocrystals.

\subsection{Water vapor permeability}

Figure 6 shows the WVP of the films studied together with the MMT content. The addition of MMT particles resulted in a significant decrease in WVP in relation to the unfilled system. The MMT dispersion method had an important effect on the WVP of the resulting films. The films obtained by the M2 method presented a lower WVP in relation to those obtained by the M1 method. This behavior was related to the combined effect of the decrease in water solubility observed in Figure 4 and the longer diffusive path that the penetrating molecules had to travel as the filler concentration increased (Figure 5). Both circumstances led to a reduction in film permeability.

Method M2 resulted in a more tortuous path for the water molecules, and hence decreased solubility of the film in water than those prepared by method M1. Permeability depends on the solubility and diffusivity of the water in the polymeric matrix. According to the XRD and FTIR spectra, the greatest interaction between MMT, glycerol and starch was found in the film produced by

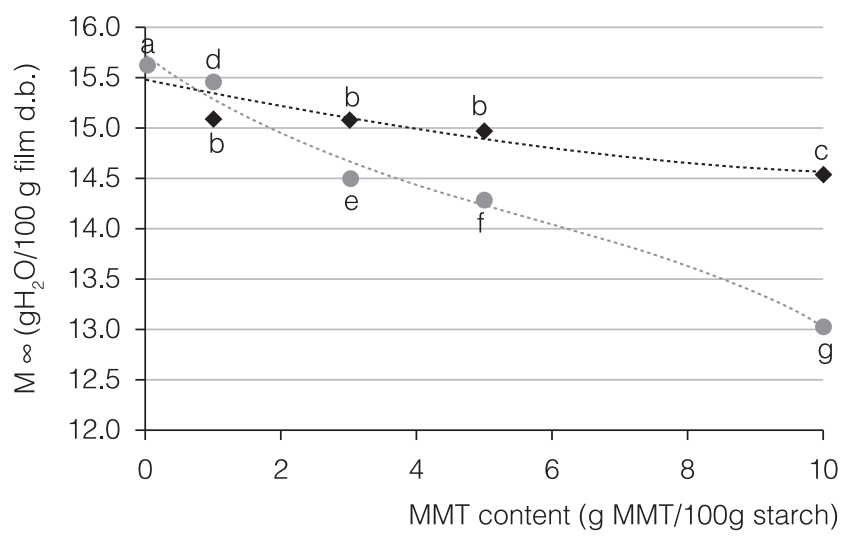

Figure 4. Water uptake $\left(M_{\infty}\right)$ of composite film as a function of MMT content prepared by M1 and M2 methods. ( $\bullet$ M1, M2). The mean difference is significant at $p \leq 0.05$. Similar letters refer equality between means.

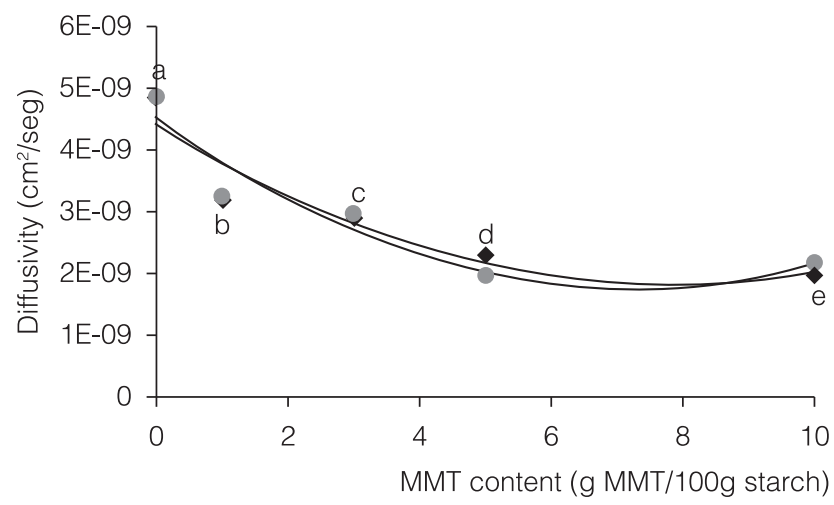

Figure 5. Diffusivity of composite film as a function of MMT content prepared by $\mathrm{M} 1$ and M2 methods. ( M1, M2). The mean difference is significant at $p \leq 0.05$. Similar letters refer equality between means. 


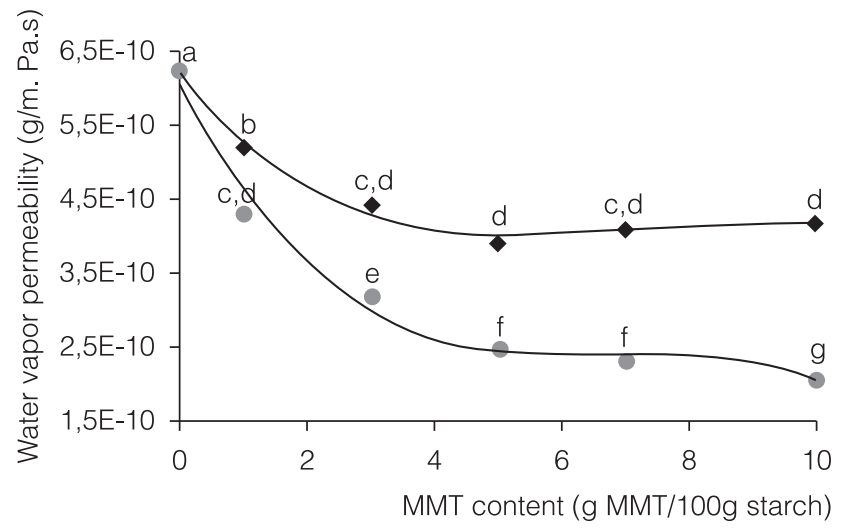

Figure 6. Water vapor permeability of composite film as a function of MMT content prepared by $\mathrm{M} 1$ and M2 methods. ( M1, M2). The mean difference is significant at $p \leq 0.05$. Similar letters refer equality between means.

method M2. Wang et al. (2009) obtained similar results with modified and unmodified MMT in starch/glycerol films, and attributed the decrease in water vapor permeability to the strong interaction of MMT with the starch and the formation of a tortuous path. Tunc et al. (2007) obtained similar results for films made of wheat gluten and MMT.

In the present study, contrary to that found by Chivrac et al. (2010), the incorporation of MMT improved the moisture barrier properties of starch based films. This could be due to differences in the MMT dispersion methods and film formation procedures used in the two cases. Chivrac et al. (2010) observed phase separation of components with the addition of $23 \%$ glycerol. The present studies demonstrated that the proposed methodology M2 led to strong interaction between the MMT and starch in an exfoliated structure up to at least $5 \%$ of MMT.

\section{Conclusions}

In the present study, starch based films with added MMT were prepared using two different methodologies. By modifying the clay dispersion technique, films were obtained with better water barrier properties, demonstrating the importance of developing techniques for the addition of nanomaterial in the polymer matrix. Starch-MMT films were obtained by casting instead of by hot pressing, as reported by other authors. The results showed that the addition of MMT using adequate methodology, improved the functional properties of the starch films due to the strong interaction between the MMT and glycerol/starch chains. The similar polar and hydrophilic characters of the polymer matrix and the MMT led to strong adhesion between them via hydrogen bonding. The decrease in film solubility and opacity and the improvement in water vapor barrier properties with the addition of nanoparticles at percentages below 10\% showed that the properties of these nanocomposites had excellent potential for their application in the technology of biopolymer based films.

\section{Acknowledgments}

The authors are grateful for the financial support provided by the Consejo de Investigaciones de la Universidad Nacional de Salta (CIUNSa), Agencia Nacional de Promoción Científica y Tecnológica (ANPCyT) and Instituto de Investigaciones para la Industria Química (INIQUI).

\section{References}

ALMASI, H.; GHANBARZADEH, B.; ENTEZAMI, A. A. Physicochemical properties of starch-CMC-nanoclay biodegradable films. International Journal of Biological Macromolecules, Oxford, v. 46, n. 1, p. 1-5, 2010. http://dx.doi. org/10.1016/j.ijbiomac.2009.10.001

AMERICAN SOCIETY FOR TESTING AND MATERIALS - ASTM. D1003: Standard Test Method for Haze and Luminous Transmittance of Transparent Plastics. West Conshohocken: ASTM International, 2007.

AMERICAN SOCIETY FOR TESTING AND MATERIALS - ASTM. E96: Standard Test Methods for Water Vapor Transmission of Materials. West Conshohocken: ASTM International, PA. 2000.

AZEREDO, H. M. Nanocomposites for food packaging applications. Food Research International, Oxford, v. 42, n. 9, p. 1240-1253, 2009. http://dx.doi.org/10.1016/j. foodres.2009.03.019

BERTUZZI, M. A.; ARMADA, M.; GOtTIfREDI, J. C. Physicochemical characterization of starch based films. Journal of Food Engineering, Oxford, v. 82, n. 1, p. 17-25, 2007. http:// dx.doi.org/10.1016/j.jfoodeng.2006.12.016

CHEN, B.; JULIAN, R.; EVANS, G. Thermoplastic starch-clay nanocomposites and their characteristics. Carbohydrate Polymers, Oxford, v. 6, n. 4, p. 455-463, 2005. http://dx.doi. org/10.1016/j.carbpol.2005.06.020

CHIVRAC, F.; POLLET, E.; AVÉROUS, L. Progress in nanobiocomposites based on polysaccharides and nanoclays. Materials Science and Engineering, Oxford, v. 67, n. 1, p. 1-17, 2009. http://dx.doi.org/10.1016/j.mser.2009.09.002

CHIVRAC, F.; POLLET, E.; DOLE, P.; AVÉROUS, L. Starchbased nano-biocomposites: Plasticizer impact on the montmorillonite exfoliation process. Carbohydrate Polymers, Oxford, v. 79, n. 4, p. 941-947, 2010. http://dx.doi.org/10.1016/j. carbpol.2009.10.018

CHUNG, Y. L.; ANSARI, S.; ESTEVEZ, L.; HAYRAPETYAN, S.; GIANNELIS, E. P.; LAI, H. M. Preparation and properties of biodegradable starch-clay nanocomposites. Carbohydrate Polymers, Oxford, v. 79, n. 2, p. 391-396, 2010. http://dx.doi. org/10.1016/j.carbpol.2009.08.021 
COLE, K. C. Use of infrared spectroscopy to characterize clay intercalation and exfoliation in polymer nanocomposites. Macromolecules, Washington, v. 41, n. 3, p. 834-843, 2008. http://dx.doi.org/10.1021/ma0628329

CRANK, J. The Mathematics of Diffusion. Oxford: Clarendon Press, 1975. $414 \mathrm{p}$

CYRAS, P.; MANFREDI, L.; TON-THAT, M.; VÁZQUEZ, A. Physical and mechanical properties of thermoplastic starch/ montmorillonite nanocomposite films. Carbohydrate Polymers, Oxford, v. 73, n. 1, p. 55-63, 2008. http://dx.doi.org/10.1016/j. carbpol.2007.11.0014

DEAN, K.; DO, M.; PETINAKIS, E.; YU, L. Key interactions in biodegradable thermoplastic starch/poly(vinyl alcohol)/ montmorillonita micro and nanocomposites. Composites Science and Technology, Oxford, v. 68, n. 6, p. 1453-1462, 2008. http://dx.doi.org/10.1016/j.compscitech.2007.10.037

DENNIS, H. R.; HUNTER, D. L.; CHANG, D.; KIM, S.; WHITE, J. L.; CHO, J. W.; PAUL, D. R. Effect of melt processing conditions on the extent of exfoliation in organoclay based nanocomposites. Polymers, Oxford, v. 42, n. 23, p. 9513-9522, 2001. http://dx.doi. org/10.1016/S0032-3861(01)00473-6

FORSELL, P.; LAHTINEN, R.; LAHELIN, M.; MYLLÄRINEN, P. Oxygen permeability of amylose and amylopectin films. Carbohydrate Polymers, Oxford, v. 47, n. 2, p. 125-129, 2002. http://dx.doi.org/10.1016/S0144-8617(01)00175-8

GONTARD, N.; GUILBERT, S.; CUQ, J. Edible wheat gluten films: influence of main process variables on film properties using response surface methodology. Journal Food Science, Malden, v. 57, n. 1, p. 190-199, 1992. http://dx.doi. org/10.1111/j.1365-2621.1992.tb05453.x

GUILBERT, S.; GONTARD, N.; CUQ, B. Technology and applications of edible protective films. Packaging Technology and Science, Malden, v. 8, n. 6, p. 339-346, 1995. http://dx.doi. org/10.1002/pts.2770080607

HUANG, M.; YU, J.; MA, X. High mechanical performance MMT-urea and formamide-plasticized thermoplastic cornstarch biodegradable nanocomposites. Carbohydrate Polymers, Oxford, v. 63, n. 3, p. 393-399, 2006. http://dx.doi.org/10.1016/j. carbpol.2005.09.006

KESTER, J. J.; FENNEMA, O. R. Edible films and coatings: A review. Food Science and Technology, Oxford, v. 40, n. 4, p. 47-59, 1986.

KRISTO, E.; BILIADERIS, C. G. Physical properties of starch nanocrystal-reinforced pullulan film. Carbohydrate Polymers, Oxford, v. 68, n. 1, p. 146-158, 2006. http://dx.doi.org/10.1016/j. carbpol.2006.07.021

LIU, H.; CHAUDHARY, D.; YUSA, S. I.; TADÉ, M. O. Glycerol/ starch/Na+-montmorillonite nanocomposites: A XRD, FTIR, DSC and $1 \mathrm{H}$ NMR study. Carbohydrate Polymers, Oxford, v. 83 , n. 4, p. 1591-1597, 2011. http://dx.doi.org/10.1016/j. carbpol.2010.10.018

MAJDZADEH-ARDAKANI, K.; NAVARCHIAN, A.; SADEGHI, F. Optimization of mechanical properties of thermoplastic starch/ clay nanocomposites. Carbohydrate Polymers, Oxford, v. 79, n. 3, p. 547-554, 2010. http://dx.doi.org/10.1016/j. carbpol.2009.09.001

McGLASHAN, S.; HALLEY, P. J. Preparation and characterization of biodegradable starch-based nanocomposite materials. Polymer International, Malden, v. 52, n. 11, p. 1767-773, 2003. http://dx.doi.org/10.1002/pi.1287

MORILLON, V.; DEBEAUFORT, F.; BLOND, G.; CAPELLE, M.; VOILLEY A. Factors affecting the moisture permeability of lipidbased edible films: a review. Critical Review Food Science, United Kingdom, v. 42, n. 1, p. 67-89, 2002. http://dx.doi. org/10.1080/10408690290825466

NING, W.; XINGXIANG, Z.; NA, H.; SHIHE, B. Effect of citric acid and processing on the performance of thermoplastic starch/ montmorillonite nanocomposites. Carbohydrate Polymers, Oxford, v. 76, n. 1, p. 68-73, 2009. http://dx.doi.org/10.1016/j. carbpol.2008.09.021

PARK, H. J. Development of advanced edible coating for fruits. Trends Food Science Technology, Oxford, v. 10, n. 8, p. 254-260, 1999. http://dx.doi.org/10.1016/S09242244(00)00003-0

PARK, H. M.; LI, X.; JIN, C. Z.; PARK, C. Y.; CHO, W. J.; HA, C. K. Preparation and properties of biodegradable thermoplastic starch/clay hybrids. Macromolecular Materials and Engineering, Malden, v. 287, n. 8, p. 553-558, 2002. http:// dx.doi.org/10.1002/1439-2054(20020801)287:8<553::AIDMAME553>3.0.CO;2-3

PAUL, D. R.; ROBESON, L. M. Polymer nanotechnology: Nanocomposites. Polymers, Oxford, v. 49, n. 15, p. 3187-3204, 2008. http://dx.doi.org/10.1016/j. polymer.2008.04.017

PERDOMO, J.; COVA, A.; SANDOVAL, A.; GARCÍA, L.; LAREDO, E.; MÜLLER, L. Glass transition temperatures and water sorption isotherms of cassava starch. Carbohydrate Polymers, Oxford, v. 76, n. 2, p. 305-313, 2009. http://dx.doi.org/10.1016/j. carbpol.2008.10.023

PERRINE, B.; POLLET, E.; AVERUS, L. Nano-biocomposites: Biodegradable polyester/nanoclay systems. Progress in Polymer Science, Oxford, v. 34, n. 2, p. 125-155, 2008. http:// dx.doi.org/10.1016/j.progpolymsci.2008.10.002

POOLE, C. P.; OWENS, F. J. Introducción a la Nanotecnología. Madrid: Editorial Reverté, 2007. 417 p.

RAHMAN, M. Manual de Conservación de los Alimentos. Madrid: Editorial Acribia, 2003. 863 p. 
RAY, S.; OKAMOTO, M. Polymer/layered silicate nanocomposites: a review from preparation to processing. Progress in Polymers Science, Oxford, v. 28, n. 11, p. 1539-1641, 2003. http://dx.doi. org/10.1016/j.progpolymsci.2003.08.002

STRAWHECKER, K. E.; MANIAS, E. Structure and properties of poly(vinyl alcohol)/ $/ \mathrm{Na}^{+}$-montmorillonite nanocomposites. Chemical Mater, Washington, v. 12, n. 10, p. 2943-2949, 2000. http://dx.doi.org/10.1021/cm000506g

TANG, X.; ALAVI, S.; HERALD, T. J. Effects of plasticizers on the structure and properties of starch-clay nanocomposite films. Carbohydrate Polymers, Oxford, v. 74, n. 3, p. 552-558, 2008. http://dx.doi.org/10.1016/j.carbpol.2008.04.022

TUNC, S.; ANGELLIER, H.; CAHYANA, Y.; CHALIER, P.; GONTARD, N.; GASTALDI, E. Functional properties of wheat gluten/montmorillonite nanocomposite films processed by casting. Journal of Membrane Science, Oxford, v. 289, n. 1-2, p. 159-168, 2007. http://dx.doi.org/10.1016/j. memsci.2006.11.050

TUNÇ, S.; OSMAN, D. Preparation and characterization of biodegradable methyl cellulose/montmorillonita nanocomposite films. Applied Clay Science, Oxford, v. 48, n. 3, p. 414-424, 2010. http://dx.doi.org/10.1016/j.clay.2010.01.016
WANG, N.; ZHANG, X.; HAN, N.; BAI, S. Effect of citric acid and processing on the performance of thermoplastic starch/ montmorillonite nanocomposites. Carbohydrate Polymers, Oxford, v. 76, n. 1, p. 68-73, 2009. http://dx.doi.org/10.1016/j. carbpol.2008.09.021

WEISS, J.; TAKHISTOV, P.; McCLEMENTS, J. Functional materials in food nanotechnology. Journal of Food Science, Malden, v. 71, n. 9, p. 215-223, 2006. http://dx.doi.org/10.1111/j.17503841.2006.00195.x

WILHELM, H. M.; SIERAKOWSKI, M. R.; SOUZA, G. P.; WYPYCH, F. Starch films reinforced with mineral clay. Carbohydrate Chemistry, Oxford, v. 52, n. 2, p. 101-110, 2003. http://dx.doi. org/10.1016/S0144-8617(02)00239-4

XIONG, H.; TANG, S. W.; TANG, H.; ZOU, P. The structure and properties of starch-based biodegradable film. Carbohydrate Polymers, Oxford, v. 71, n. 2, p. 263-268, 2007. http://dx.doi. org/10.1016/j.carbpol.2007.05.035

YU, Y.; LIN, C.; YEH, J.; LIN, W. Preparation and properties of poly(vinyl alcohol)-clay nanocomposite materials. Polymers, Oxford, v. 44, n. 12, p. 3553-3560, 2003. http://dx.doi. org/10.1016/S0032-3861(03)00062-4 